\title{
PENGEMBANGAN BAHAN AJAR RIDDLE STORY BOOK MATERI SISTEM RANGKA MANUSIA KELAS XI SMU
}

\author{
Sulmiati Sari \\ UIN Alauddin Makassar, Kampus II Jl. H. M. Yasin Limpo \\ No 36 Samata-Gowa, Sulawesi Selatan 92118, Telepon: (0411) 424835, \\ E-mail: mitamustabil@gmail.com

\begin{abstract}
Ainul Uyuni Taufiq
UIN Alauddin Makassar, Kampus II J1. H. M. Yasin Limpo

No 36 Samata-Gowa, Sulawesi Selatan 92118, Telepon: (0411) 424835,

E-mail: ainul.uyuni@uin-alauddin.ac.id
\end{abstract}

\section{Muhammad Yusuf Tahir} \\ UIN Alauddin Makassar, Kampus II J1. H. M. Yasin Limpo \\ No 36 Samata-Gowa, Sulawesi Selatan 92118, Telepon: (0411) 424835, \\ E-mail: yusuftahir@uin-alauddin.ac.id
}

\begin{abstract}
Abstrak
Penelitian ini bertujuan menghasilkan produk bahan ajar berbasis riddle story. Dilatarbelakangi oleh hasil penelitian awal yang menunjukkan bahwa buku paket kurang menarik dan membuat siswa bosan menggunakannya dalam belajar. Jenis penelitian ini adalah penelitian dan pengembangan atau researh and development yaitu metode penelitian yang digunakan untuk meneliti dan menghasilkan produk tertentu serta menguji efektifitas penggunaan produk tersebut untuk mencapai tujuan. Proses penelitiannya berusaha mendapatkan gambaran tentang bahan bejar yang digunakan siswa dan pengembangannya mengacu pada model pengembangan 4D yang dikolaborasikan dengan model pengembangan Borg dan Gall yang terdiri dari 4 (empat) tahap yaitu tahap pendefenisian, tahap perancangan, tahap pengembangan dan tahap penyebaran. Penelitian ini difokuskan kepada deskripsi kebutuhan siswa terhadap bahan ajar, proses pengembangan dan keefektifan bahan ajar dalam mengantar siswa menguasai kompetensinya. Data hasil penelitian ini dianalisis secara kualitatif untuk menguji bahan ajar ini sehingga memenuhi kriteria layak pakai.
\end{abstract}

Kata Kunci : Pengembangan Bahan Ajar, Riddle Story Book, Biologi Puzzle

\begin{abstract}
This study aims to produce a riddle story-based teaching materials. Backed up by the results of preliminary research that shows that the book package is less interesting and makes students tired of using it in learning. This type of research
\end{abstract}


is research and development or researh and development of research methods used to examine and produce specific products and test the effectiveness of the use of these products to achieve the goal. The research process seeks to get an idea of the subject matter used by the students and its development refers to the $4 D$ development model collaborated with the Borg and Gall development model consisting of 4 (four) phases that is define, design, development, and disseminate. This study focused on the description of the students' needs on teaching materials, development process and the effectiveness of teaching materials in delivering students to master their competence. The data of this research are analyzed qualitatively to test this instructional material so that it meets the criteria worthy to use.

Key word: Development of teaching materials, Riddle story book, Biology puzzle.

\section{PENDAHULUAN}

Belajar adalah hal penting dalam peradaban manusia dan menjadi penciri yang membedakan makhluk manusia dengan lainnya. Kemampuan manusia belajar memberi efek besar bagi perubahan lingkungan kehidupan. Terlepas dari sisi negatif perubahan itu, akselerasi belajar manusia telah membuktikan manusia mampu memenuhi kebutuhan secara lebih efektif dan efisien (Yusuf: 2013).

Ilmu pengetahuan yang menjadi produk belajar sejak lama dijadikan indikator pembeda diantara makhluk. Al Quran yang menjadi rujukan utama ajaran Islam mengapresiasi mereka yang menguasai ilmu pengetahuan yang ditunjukkan dengan diwajibkannya kita untuk memiliki ilmu pengetahuan. Allah dalam QS AlMujadalah/58 : 11 berfirman:

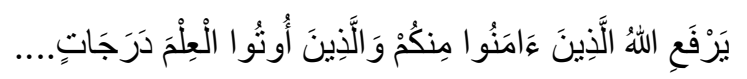

Terjemahan: “...Allah akan meninggikan orang-orang yang beriman di antaramu dan orang-orang yang diberi ilmu pengetahuan....” (QS.Al-Mujadalah:11)

Menurut Shihab (2002), maksud dari ayat di atas adalah ada diantara manusia yang diangkat derajatnya oleh Allah, yaitu orang-orang yang beriman dan orang-orang yang berilmu pengetahuan. Derajat orang yang beriman dan berilmu pengetahuan diangkat karena mereka akan menunjukkan sikap arif dan bijaksana. Arif artinya orang itu akan bertindak dan berperilaku menurut pengetahuannya ('irfaan) sedang bijaksana akan membuatnya memiliki pertimbangan dalam memutuskan suatu amalan. Iman dan ilmu tersebut akan membuat orang mantap dan agung. Tentu saja yang dimaksud 
dengan berilmu itu artinya yang diberi pengetahuan. Ini berarti pada ayat tersebut membagi kaum beriman pada dua kelompok besar, yang pertama sekedar beriman dan beramal saleh, dan yang kedua adalah yang beriman dan beramal saleh serta memiliki ilmu pengetahuan. Derajat kelompok kedua ini lebih tinggi, bukan saja karena nilai ilmu yang disandangnya tapi juga amal dan pengajarannya kepada pihak lain baik secara lisan, tulisan maupun keteladanan.

Biologi merupakan salah satu cabang ilmu pengetahuan yang khusus mempelajari gejala alam dan sekumpulan konsep-prinsip-teori (produk sains), cara kerja atau metode ilmiah (proses sains), dan di dalamnya terkandung sejumlah nilai dan sikap. Untuk mempelajari biologi, kita memerlukan metode yang berbeda-beda, sebab ilmu biologi memiliki konsep yang berbeda berdasarkan objek kajiannya (Asrijal, 2016). Saat ini, proses pembelajaran biologi dilakukan dengan metode yang monoton, bertumpu pada strategi ekspositori (Yusuf: 2013). Kebanyakan dari metode ini hanya akan menghasilkan produk berupa hafalan, padahal konsep biologi tidak hanya hafalan, akan tetapi juga konten yang membutuhkan kerja kognitif tinggi. Hal ini menunjukan bahwa untuk mempelajari biologi, maka diperlukan sumber belajar yang lebih banyak dan bervariasi. Salah satu sumber belajar yang baik untuk digunakan adalah bahan ajar (Suartika, Arnyana dan Setiawan, 2013).

Selain strategi belajar yang harus diperbaiki, penunjang keberhasilan belajar lainnya adalah bahan belajar (Yusuf: 2016). Bahan ajar merupakan unsur yang amat penting dalam pembelajaran. Tanpa bahan ajar, mustahil tujuan pembelajaran akan tercapai dan kompetensi dasar peserta didik (Wahyudi, Hariyadi dan Hariani, 2014). Berangkat dari asumsi ini, peneliti menelusuri penggunaan bahan ajar oleh siswa khususnya di daerah Makassar dan Gowa, dan hasilnya masih berada dalam kategori rendah. Diantara pernyataan umum dalam penelitian awal menyatakan bahwa dalam pelaksanaan proses pembelajaran biologi masih didominasi oleh penggunaan metode ceramah dengan aplikasi power point, dan buku paket sekolah.

Minimnya perhatian guru terhadap penggunaan sumber belajar yang bervariasi menjadi salah satu penyebab kurangnya minat siswa dalam kegiatan pembelajaran. Apalagi bila dikaitkan dengan materi sistem rangka manusia dalam pembelajaran biologi. Penguasaan materi ini relatif membutuhkan bahan dan sumber yang bervariasi sehingga pemahaman atas kontennya relatif kuat dan komprehensif. Kurangnya bahan akan mengakibatkan proses belajar yang membosankan seperti ditunjukkan oleh hasil observasi peneliti di SMA Negeri 9 Gowa, yang menunjukkan umumnya siswa merasa bosan mempelajari materi tersebut.

Menanggapi hal ini, peneliti merasa bahwa guru sangat memerlukan beberapa hal untuk meningkatkan semangat belajar siswanya, salah satunya dengan menyediakan bahan ajar yang baru dan menyenangkan. Berkaitan dengan kriteria tersebut, maka peneliti memilih teka-teki sebagai ciri khas dari bahan ajar ini. Dalam bahasa Inggris, istilah teka-teki biasa disebut dengan riddle. Menurut Kamus Besar Bahasa Indonesia, teka-teki merupakan soal yang berupa kalimat (cerita, gambar) yang dikemukakan secara samar-samar, biasanya sebagai permainan untuk menghibur atau untuk mengasah 
pikiran (Alwi, 2007). Teka-teki merupakan refleksi dari budaya suatu masyarakat yang dipertahankan dengan penyampaian dari mulut ke mulut berupa pertanyaan yang di dalamnya terdapat metafora, kontradiksi dan ambiguitas sedangkan jawabannya tersirat dalam pertanyaan tersebut (A. Noss, 2006).

Menurut Thompson (1999), teka-teki merupakan salah satu jenis folklor yang membudaya di masyarakat. Penyebarannya berasal dari mulut ke mulut, sehingga tidak banyak folklorists yang mengkajinya. Meski begitu, ternyata teka-teki tidak terdapat hanya pada satu daerah saja, tetapi menyebar luas ke berbagai belahan dunia dengan genre dan fungsi yang berbeda-beda tergantung pada negara mana teka-teki itu berasal. Terdapat beberapa jenis teka-teki, menurut Robert A. Georges dan Alan Dundes dalam Danandjaja (1984), ada dua jenis teka-teki secara umum, yaitu: (1) teka-teki tidak bertentangan, yaitu teka-teki yang tidak bertentangan unsur-unsur pelukisannya bersifat harfiah, yakni seperti apa yang tertulis (literal), atau kiasan (metaphorikal), dan (2) teka-teki bertentangan, yaitu teka-teki yang memiliki unsur pertentangan antara sepasang atau lebih unsur pelukisannya.

Di tempat lain, Im Young Ho dalam Ningsih, Atmazaki dan Syahrul (2013), mengelompokkan teka-teki menjadi lima kelompok, yaitu; 1) teka-teki permainan kata, yaitu teka-teki yang berasal dari rangkaian kata yang dituturkan secara kreatif; 2) tekateki terkaan, yaitu teka-teki berupa pertanyaan yang mana pertanyaan tersebut diungkapkan secara metafora; 3) teka-teki soalan, yaitu teka-teki yang cendrung bertumpu pada permainan kata suatu bahasa berupa permaina bunyi, permainan suku kata; 4) teka-teki permainan wacana, yaitu teka-teki yang umumnya menyajikan pertanyaan dengan mendeskripsikan suatu masalah untuk dianalisis; dan 5) teka-teki plesetan, yaitu teka-teki yang memperlihatkan hadirnya plesetan (perubahan kata) dalam unsur jawaban.

Tidak hanya sebagai permainan, Jordhan-Smith (2004) menerangkan bahwa seiring dengan waktu dan pergeseran budaya, teka-teki juga mengalami transformasi klasik menjadi berbagai bentuk lelucon. Namun fungsi teka-teki dapat dikondisikan tergantung di mana teka-teki dimainkan seperti dalam kontes dan permainan, atau upacara adat tertentu. Fungsi teka-teki menurut Hamidy (1995) yang kemudian diterangkan oleh beberapa ahli lain adalah; 1) berpikir dan menyampaikan pendidikan.

Uraian di atas menunjukan beberapa hal mengenai teka-teki terkait dengan pembelajaran oleh karena itu peneliti merancang suatu penelitian dengan judul pengembangan bahan ajar riddle story book materi sistem rangka manusia kelas XI SMU. Dalam penelitian ini peneliti akan melihat bahwa apakah riddle story book yang dirancang benar dibutuhkan oleh siswa kelas XI SMU, kemudian peneliti akan membahas mengenai proses perancangan bahan ajar riddle story book, dan yang terakhir yaitu peneliti akan melihat keefektifan dari riddle story book yang telah dirancang. 


\section{METODOLOGI PENELITIAN}

Jenis penelitian yang digunakan dalam penelitian ini adalah penelitian dan pengembangan (researh and development) yaitu metode penelitian yang digunakan untuk menghasilkan produk tertentu dan menguji keefektifan produk tersebut (Sugiyono, 2003). Untuk model pengembangan, peneliti memilih untuk memadukan antara model 4-D dengan model Borg and Gall. Model Borg and Gall khusus digunakan pada tahap uji coba. Penelitian ini dimulai pada tanggal 10 Januari 2017 sampai dengan 28 Agustus 2017. Uji coba produk yang berupa bahan ajar riddle story book materi sistem rangka manusia dilaksanakan pada tanggal 28 Agustus 2017 di SMA Negeri 9 Gowa. Yang menjadi objek uji coba adalah semua siswa kelas XI Jurusan MIA SMU. Namun, dikarenakan sulitnya mencapai keseluruhan objek yang dimaksud, maka peneliti fokus memilih siswa dengan kualifikasi sama pada siswa SMU di sekitar Makassar dan Gowa. Dalam hal ini peneliti memilih siswa SMA Negeri 9 Gowa dan siswa kelas XI MIA 4 sebagai subjek penelitian ini.

Pelaksanaan penelitian ini terdiri dari beberapa tahap berdasarkan model 4D yang dikolaborasikan dengan model Borg and Gall. Tahap pertama yang harus dilakukan adalah tahap pendefenisian. Tujuan dari tahap ini adalah menentapkan dan mendefinisikan syarat-syarat pembelajaran diawali dengan analisis tujuan dari batasan materi yang dikembangkan perangkatnya. Tahap ini sendiri terbagi menjadi beberapa bagian yaitu 1) analisis awal akhir yang bertujuan untuk menetapkan masalah dasar yang diperlukan dalam pengembangan perangkat pembelajaran; 2) analisis siswa yang merupakan telaah tentang karakteristik siswa yang sesuai dengan rancangan bahan ajar; 3) analisis tugas merupakan pengidentifikasian tugas atau keterampilan utama yang dilakukan siswa selama pembelajaran, kemudian menganalisisnya ke dalam suatu kerangka sub keterampilan yang lebih spesifik; 4) analisis konsep bertujuan untuk mengidentifikasi, merinci dan menyusun secara sistematis konsep-konsep yang relevan yang akan diajarkan berdasarkan analisis awal-akhir; 5) perumusan/ spesifikasi tujuan pembelajaran yang bertujuan untuk merumuskan hasil analisis tugas dan analisis konsep menjadi indikator pencapaian hasil belajar.

Tahap selanjutnya adalah tahap perancangan, yang mana pada tahap ini terdiri atas 3 langkah yaitu; 1) memilih topik yang sesuai; 2) menetapkan kriteria; dan 3) desain awal. Pada tahap perancangan rancangan awal bahan ajar selesai. Tahap selanjutnya adalah tahap pengembangan, pada tahap ini terdiri atas beberapa langkah yaitu, 1) validasi ahli yang bertujuan untuk mendapatkan masukan ahli akan kelayakan bahan ajar untuk diuji cobakan; 2) kegiatan uji pengembangan yang bertujuan untuk menguji kelayakan bahan ajar kepada siswa dalam jumlah yang ditentukan; 3) uji coba yang bertujuan untuk menguji kefektifan bahan ajar yang dikembangkan; 4) kegiatan revisi yang bertujuan untuk memperbaiki bahan ajar sesuai dengan koreksi yang diberikan oleh validator dan subjek uji coba; 5) kegiatan pengemasan sebagai penanda akhir kegiatan pengembangan. 
Dalam penelitian ini, peneliti menggunakan 3 jenis instrumen penelitian yaitu, 1) daftar cek masalah yang digunakan untuk mengumpulkan data berupa kebutuhan siswa terhadap bahan ajar. Isi dari instrumen ini berupa sebuah daftar kemungkinan masalah yang disusun untuk merangsang atau memancing pengutaraan masalah yang pernah atau yang sedang dialami baik oleh guru maupun peserta didik; 2) lembar penilaian produk yang digunakan untuk mengukur kevalidan bahan ajar, dan seluruh instrumen yang berpatokan pada rasional teoritik yang kuat, dan konsistensi secara internal antar komponen-komponen bahan ajar dari segi konstruksi dan isinya, yang divalidasi di sini adalah kesesuaian riddle dengan tujuan pembelajaran pada materi sistem rangka manusia; 3) lembar observasi yang digunakan untuk mengumpulkan informasi mengenai efektifitas bahan ajar yang dikembangkan.

Hasil yang dikumpulkan dari instrumen penelitian di atas akan dianalisis secara kualitatif yang terdiri atas 3 tahap yaitu reduksi data, penyajian data dan penarikan kesimpulan (Sutopo dan Arief, 2010).

\section{HASIL PENELITIAN DAN PEMBAHASAN}

Hasil penelitian dan pengembangan bahan ajar riddle story book ini dipaparkan menjadi 6 poin berdasarkan model pengembangan 4D yang dikolaborasikan dengan model Borg and Gall yang meliputi:

Pada tahap pendefenisian, khususnya pada langkah pertama yaitu analisis awal akhir peneliti menganalisis kompetensi inti dan kompetensi dasar yang dibutuhkan dalam pengembangan riddle story book sistem rangka manusia. Karena peneliti hanya fokus pada materi sistem rangka manusia maka peneliti hanya mengambil satu bagian dari KI 3, yaitu KD 3.5 spesifik pada KD 3.5.1 peserta didik mampu menganalisis struktur dan fungsi tulang penyusun tubuh manusia melalui studi literatur dengan tepat. Selanjutnya, peneliti menganalisis kebutuhan siswa. Dalam tahap ini meneliti menemukan beberapa kesulitan yang dihadapi siswa selama kegiatan pembelajaran khususnya ketika mempelajari materi sistem rangka manusia. Beberapa diantaranya yaitu, 1) siswa sulit memahami beberapa kalimat yang tersedia dalam buku paket yang menggunakan bahasa yang sangat formal; 2) siswa tidak bisa belajar dengan buku paket selain di dalam kelas; 3) siswa cepat bosan ketika membaca buku paket; 4) siswa tidak suka menghapal; dan yang terakhir yaitu 5) siswa kesulitan mengetahui dan mengingat nama-nama tulang penyusun rangka manusia beserta letak, bentuk, dan fungsinya.

Berdasarkan uraian di atas, dapat diketahui bahwa siswa membutuhkan suatu bahan ajar yang dapat mereka gunakan dengan mudah. Bahan ajar yang dimaksudkan adalah bahan ajar yang menarik, menggunakan bahasa yang mudah dipahami, mudah untuk dibawa kemana saja, dan dapat memudahkan siswa untuk menghapal namun tetap membuat siswa tetap rileks dalam belajar. Kebutuhan tersebut dapat terpenuhi dengan adanya bahan ajar riddle story book materi sistem rangka manusia pada siswa kelas XI SMU. 
Selanjutnya peneliti melakukan analisis konsep, dalam hal ini peneliti melakukan analisis kurikulum dan analisis kebutuhan siswa. Oleh karena guru biologi SMA Negeri 9 Gowa menggunakan kurikulum 2013, maka peneliti akan mengembangkan bahan ajar yang sesuai dengan standar kurikulum tersebut. Karena peneliti memilih teka-teki sebagai ciri utama dalam bahan ajar yang dikembangkan, maka peneliti akan melakukan penyesuaian jenis teka-teki yang digunakan dengan indikator-indikator yang akan dicapai dalam proses pembelajaran. Dalam hal ini peneliti memilih cerita teka-teki (riddle story), yaitu suatu jenis teka-teki yang disajikan dalam bentuk cerita atau narasi.

langkah selanjutnya peneliti melakukan perumusan atau spesifikasi tujuan pembelajaran. Berdasarkan hasil analisis kurikulum dan analisis konsep, materi sistem rangka terdapat dalam KD 3.5 tepatnya pada bab sistem gerak. Bab ini terdiri dari beberapa sub bab yaitu sistem rangka, persendian dan sistem otot. Namun karena peneliti hanya mengambil materi sistem rangka saja, maka peneliti hanya mengambil satu indikator dalam KD 3.5 tepatnya pada KD 3.5.1 yaitu peserta didik mampu menganalisis struktur dan fungsi tulang penyusun tubuh manusia melalui studi literatur dengan tepat. Materi tersebut bersifat faktual, dimana cara mempelajarinya adalah dengan menghapal. Oleh karena itu, peneliti membuat bahan ajar ini untuk membatu siswa dalam mempelajari materi ini. Berdasarkan hal tersebut, peneliti merumuskan beberapa tujuan pembelajaran yang ingin dicapai yaitu:

1) agar siswa dapat mengetahui dan mengingat nama-nama tulang penyusun sistem rangka manusia; 2) agar siswa mampu menganalisis bentuk dan struktur dari tulang penyusun rangka manberusia; 3) agar siswa mampu menganalisis fungsi dari setiap tulang penyusun rangka manusia; dan 4) agar siswa mampu mengetahui letak dari masing-masing tulang penyusun rangka manusia.

Selanjutnya, peneliti melakukan tahap kedua yaitu tahap perancangan. Pada tahap ini peneliti melakukan dengan 3 langkah yaitu, 1) memilih topik bahan pelajaran yang sesuai. Pada tahap ini peneliti meninjau kembali sub-sub topik yang ada dalam materi sistem rangka manusia, kemudian menganalisis materi-materi manakah yang tepat untuk disajikan dalam bentuk riddle story. Materi yang hendak disajikan yaitu materi yang sehubungan dengan KD 3.5 yaitu menganalisis hubungan antara jaringan penyusun organ pada sistem gerak dan mengaitkan dengan bio prosesnya sehingga dapat menjelaskan mekanisme gerak serta gangguan fungsi yang mungkin terjadi pada sistem gerak manusia melalui studi literatur dengan tepat. Dalam hal ini peneliti memfokuskan pada salah satu indikator yang terdapat dalam KD tersebut yaitu nomor 3.5.1 peserta didik mampu menganalisis struktur dan fungsi tulang penyusun tubuh manusia melalui studi literatur dengan tepat.

Indikator tersebut mengharapkan agar peserta didik tidak sekedar menghafal melainkan sampai pada tingkatan menganalisis. Sementara saat ini masih banyak guru yang menggunakan metode dan bahan ajar yang hanya melatih kemampuan peserta didik untuk menghafal. Hal tersebut tidaklah salah karena pada dasarnya materi sistem rangka merupakan materi yang sifatnya faktual. Artinya cara yang paling tepat 
digunakan adalah dengan menghafal. Namun akan menjadi salah bila hanya menggunakan cara tersebut karena secara otomatis target yang diharapkan dalam indikator di atas tidak akan bisa tercapai. Maka dari itu peneliti memilih riddle story sebagai salah satu alternatif dalam pemecahan masalah ini. Karena pada umumnyan dengan teka-teki kita dapat menarik minat peserta didik untuk belajar, selain itu dapat menjadi cara yang menyenangkan bagi peserta didk untuk menghafal.

Hal ini karena peserta didik dapat dengan mudah mengingat sesuatu yang menarik apalagi jika mereka sendiri yang menemukan jawaban dari teka-teki yang disajikan. Tidak hanya mengingat tetapi juga mereka akan memahami materi yang disajikan. Hal ini karena mereka tidak akan menemukan jawaban tanpa menganalisis terlebih dahulu pertanyaan-pertanyaan disajikan. Aktivitas tersebut dapat membantu siswa untuk menyimpan jawaban yang mereka temukan di dalam memori jangka panjang mereka, sehingga mereka akan dengan mudah menghapal namun tidak merasa terbebani untuk melakukannya. 2) menetapkan kriteria. Pada tahap ini peneliti memilih beberapa kriteria yang baik untuk bahan ajar yang dikembangkan diantaranya: Pertama, bentuk buku yang tidak begitu besar agar bisa dibawa ke mana-mana. Hal ini peneliti lakukan karena peneliti melihat beberapa siswa perempuan hanya membawa tas berukuran kecil ketika ke sekolah dimana tas tersebut hanya dapat diisi dengan buku tulis dan pulpen. Hal ini menjadi alasan siswa untuk tidak membawa buku paket, ada pula yang memegang buku paketnya ketika ke sekolah. Kebiasaan tersebut manarik perhatian peneliti untuk mengembangkan buku yang berukuran kecil agar dapat masuk di dalam tas yang berukuran kecil dan tidak menyulitkan siswa untuk membawanya. Kedua, bahasa yang digunakan dalam pemaparan materi adalah bahasa yang semi formal, di mana bahasa yang dimaksud adalah bahasa yang tetap menjaga etika sopansantun dan kalimat yang baku namun tetap dekat dengan bahasa yang digunakan siswa dalam kesehariannya.

Hal ini dilakukan agar siswa mudah memahami setiap kata dalam buku ini.Ketiga, setiap penjelasan dari bagian-bagian tulang yang dijelaskan disertai dengan gambar yang menarik dan warna yang yang menarik pula. Keempat, soal-soal yang disajikan berupa cerita yang dikemas dalam bentuk teka-teki yang dapat menarik minat siswa untuk mengerjakan soal dengan semangat. Soal ini juga dapat membangun kerja sama antar siswa. Soal-soal inilah yang menjadi ciri khas dari buku ini. 3) desain awal. Pada tahap ini bahan ajar yang dikembangkan disusun berdasarkan karakteristik yang telah ditentukan selanjutnya disajikan dalam beberapa bagian yaitu meliputi halaman sampul, halaman pendukung (kata pengantar, daftar isi, daftar pustaka, dan tentang penulis), serta halaman isi. Sampul buku didesain dengan program Corel Draw.

Peneliti memilih background dengan gambar rangka manusia secara utuh. Kemudian diberi keterangan seperti judul bahan ajar, materi yang terdapat di dalam bahan ajar, kemudian sub-sub topik pembahasan dalam bahan ajar, dan kelompokkelompok teka-teki yang terdapat dalam bahan ajar. Kemudian pada bagian dalam bahan ajar, disajikan dengan jenis huruf irishUPC berukuran 14pt. Dalam setiap penjelasan materi selalu disertai dengan gambar-gambar yang relevan dan warna yang 
menarik. Tahap selanjutnya adalah tahap pengembangan. Langkah pertama pada tahap ini, yaitu dengan melakukan validasi pada bahan ajar. Validasi bahan ajar dilakukan untuk menguji validitas atau kelayakan bahan ajar sebelum diterapkan pada tahap selanjutnya. Validitas yang dimaksud dalam pengembangan bahan ajar ini adalah transferability atau dalam penelitian kuantitatif dikenal dengan validitas eksternal. Yang mana transferability ini menunjukkan derajat ketepatan atau dapat diterapkannya hasil penelitian ke populasi di mana sampel tersebut diambil. Validasi yang dilakukan terhadap bahan ajar meliputi validasi oleh ahli materi dan validasi oleh ahli konten. Validator ahli materi berperan untuk mengevaluasi materi biologi yang terkandung dalam bahan ajar yang dikembangkan. Sedangkan validator ahli konten berperan untuk mengevaluasi penampilan dari bahan ajar.

Selama proses validasi berlangsung, validator memberikan beberapa saran kepada peneliti untuk melakukan perbaikan terhadap bahan ajar yang dikembangkan. Perbaikan tersebut dilakukan secara mendetail dari halaman sampul hingga isi yang terkandung di dalamnya. Kritik dan saran tersebut dapat dilihat pada tabel 1:

Tabel 1. Kritik dan saran perbaikan bahan ajar dari validator

\begin{tabular}{|c|c|c|c|}
\hline No & $\begin{array}{c}\text { Jenis } \\
\text { perbaikan }\end{array}$ & Kritik & Saran perbaikan \\
\hline & & $\begin{array}{l}\text { 1. Gambar yang digunakan } \\
\text { terlihat terlalu ramai } \\
\text { 2. Warna tulisan hampir menyatu } \\
\text { dengan background } \\
\text { 3. Ukuran tulisan terlalu kecil }\end{array}$ & $\begin{array}{l}\text { 1. Desain sampul dengan } \\
\text { background yang simpel } \\
\text { 2. Gunakan warna-warna } \\
\text { yang cerah }\end{array}$ \\
\hline 1 & Sampul & 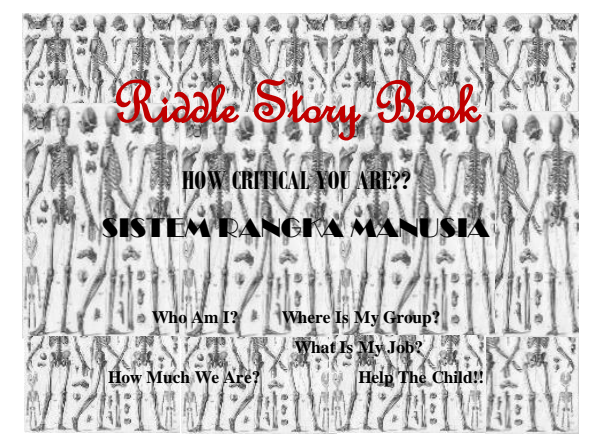 & 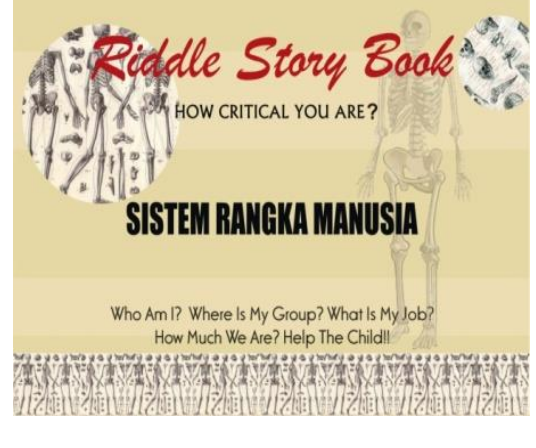 \\
\hline 2 & Isi & $\begin{array}{l}\text { 1. Jangan menggunakan gambar } \\
\text { internet dengan tulisan } \\
\text { 2. Sumber gambar tidak ada } \\
\text { 3. Format penulisan keterangan } \\
\text { gambar masih keliru }\end{array}$ & $\begin{array}{l}\text { 1. Gunakan gambar internet } \\
\text { yang lebih jelas } \\
\text { 2. Cantumkan sumber gambar } \\
\text { 3. Ganti format penulisan } \\
\text { keterangan gambar menjadi } \\
\text { "G 1. Keterangan gambar" }\end{array}$ \\
\hline
\end{tabular}




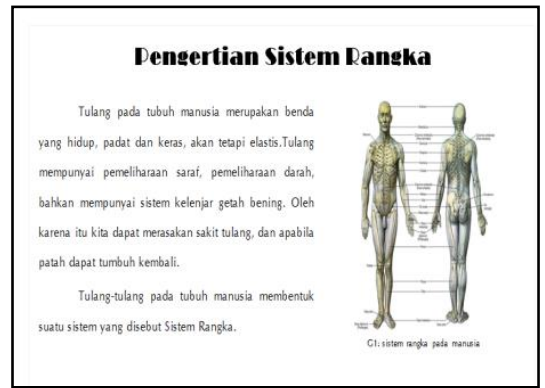

Ada materi yang tidak disertai dengan gambar

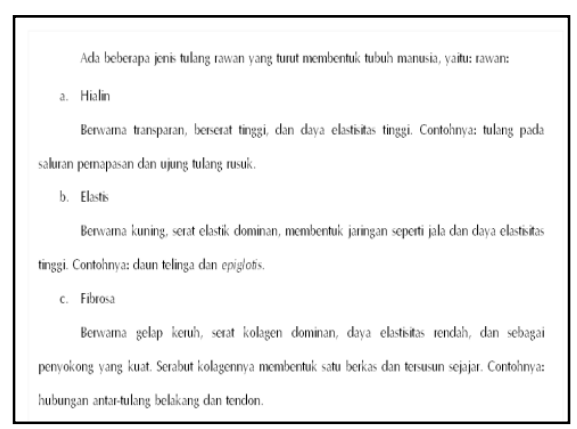

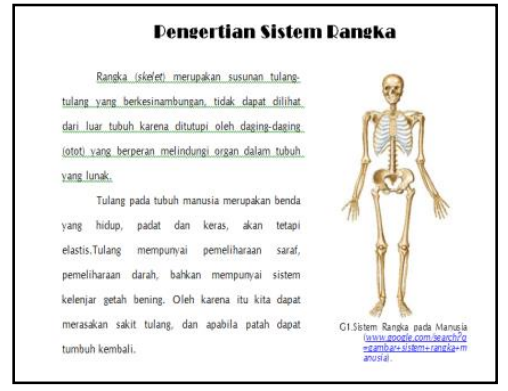

Cantumkan gambar pada setiap materi

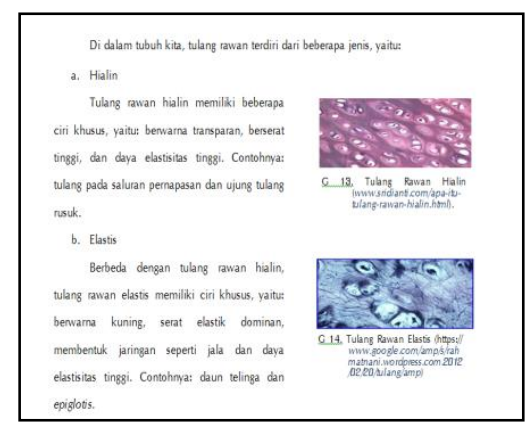

Setelah melakukan koreksi terhadap bahan ajar, validator kemudian mengisi lembar validasi yang telas disediakan peneliti untuk memberikan keterangan bahwa bahan ajar riddle story book materi sistem rangka manusia pada kelas XI SMU telah layak digunakan atau tidak. Lembar validasi tersebut berisi beberapa kriteria kevalidan bahan ajar.

Penilaian dari validator kemudian dianalisis secara kualitatif melalui tahap reduksi data, display data dan penarikan kesimpulan. Pada tahap ini, data yang diperoleh adalah nilai yang dituliskan peneliti dalam lembar validasi.

Pada menilaian oleh ahli konten, validator memberikan nilai yang beragam tergantung dari aspek yang dinilai. Pada aspek bahasa validator I memberikan total nilai 21 sedangkan validator II memberikan total nilai 20. Pada aspek penyajian validator I memberikan total nilai 17 sementara validator II memberikan total nilai 18. Pada aspek efek terhadap strategi pembelajaran validator I memberikan nilai 20 sedangkan validator II memberikan nilai 21. Pada aspek penampilan validator I memberi nilai 33 sedangkan validator II memberikan nilai 34. Berdasarkan penilaian di atas, dapat dilihat bahwa skor maksimal dari semua aspek yang dinilai hampir tercapai, di mana skor maksimal dari aspek bahasa adalah 25, aspek penyajian 20, aspek efek terhadap strategi pembelajaran 25, dan aspek penampilan 40. Dari hasil tersebut dapat dikatakan bahwa bahan ajar yang dikembangkan sudah layak untuk digunakan ditinjau dari keempat aspek tersebut. 
Pada penilaian oleh ahli materi, validator memberikan nilai yang cukup baik utnuk aspek materi bahan ajar, di mana validator I memberikan nilai 54, validator II memberikan nilai 55 dan validator III memberikan nilai 52. Dari penilaian tersebut dapat dilihat bahwa nilai yang diberikan oleh validator untuk aspek materi bahan ajar semuanya hampir mencapai skor maksimal, di mana skor maksimal untuk penilaian aspek materi adalah 65. Berdasarkan penilaian tersebut dapat dikatakan bahwa bahan ajar yang dikembangkan sudah layak digunakan ditinjau dari segi materi.

Ditinjau dari penilaian ahli media dan ahli materi, maka dapat disimpulkan bahwa bahan ajar riddle story book materi sistem rangka manusia pada kelas XI SMU sudah layak digunakan dalam kelanjutan penelitian ini. Bahan ajar yang telah divalidasi tersebut kemudian disebut sebagai prototipe 1 .

Langkah selanjutnya, peneliti melakukan kegiatan uji pengembangan. Kegiatan uji pengembangan dilakukan mengikuti tahap evaluasi menurut Borg and Gall, yaitu; 1) one to one. Pada tahap one to one bahan ajar akan diuji cobakan pada 3 sampai 5 siswa. Pada tahap ini peneliti memilih 5 siswa secara acak tanpa suatu patokan. Hal ini dilakukan dengan tujuan agar peneliti mendapatkan informasi mengenai kemampuan siswa sebelumnya. peneliti kemudian membagikan bahan ajar kepada siswa tersebut untuk dibaca di rumah mengingat waktu yang tidak mencukupi bila dilaksanakan di sekolah. Siswa tersebut membutuhkan waktu 2 hari untuk selesai membaca bahan ajar yang diberikan; 2) small group investigation. Setelah berselang 4 hari setelah uji coba one to one, peneliti kembali ke sekolah untuk melanjutkan kegiatan penelitian ke tahap small group investigation. Pada tahap ini peneliti memilih 8 siswa di mana 5 orang di antaranya adalah siswa yang dipilih pada tahap one to one sedangkan 3 orang lainnya adalah siswa yang dipilih berdasarkan nilai hasil belajar mereka. Peneliti kemudian membagikan bahan ajar yang telah dikembangkan kepada siswa tersebut untuk membacanya dan mengerjakan soal yang tersedia. Sampai pada tahap ini siswa memberikan kritik pada kesalahan pengetikan di beberapa halaman. Setelah itu peneliti melakukan revisi terhadap hal tersebut.

Langkah selanjutnya, peneliti melakukan kegiatan uji coba. Kegiatan uji coba dilakukan dengan menggunakan tahap evaluasi yang ketiga menurut Borg and Gall yaitu field trial. Pada tahap ini bahan ajar yang telah dikembangkan akan diuji cobakan pada satu kelas yaitu kelas XI MIA 4 SMA Negeri 9 Gowa yang berjumlah 36 orang, namun ketika kegiatan ini dilaksanakan 2 orang dari mereka tidak hadir untuk mengikuti pelajaran. Sebelum kegiatan pembelajaran dilaksanakan, peneliti menjelaskan maksud dari bahan ajar yang telah dikembangkan.

Selain itu peneliti juga menjelaskan cara menggunakan dan manfaat menggunakan riddle story book tersebut. Setelah itu proses pembelajaran pun mulai berlangsung, materi dalam riddle story book disampaikan oleh guru biologi. Sementara itu siswa menyimak penjelasan dari guru. Setelah menyimak materi, siswa kemudian dibagi menjadi 5 kelompok untuk menyelesaikan setiap soal yang sebelumnya memang sudah dikelompokkan berdasarkan tipe soal. Untuk mengamati kegiatan siswa selama proses pembelajaran, peneliti membawa 3 orang sebagai observer, selain 3 observer 
tersebut, guru yang mengajar juga berperan sebagai observer. Dalam proses pembelajaran, guru menyampaikan materi dalam kegiatan inti. Materi disampaikan secara lengkap oleh guru pengampu.

Dalam kegiatan ini, guru menggunakan torso dan gambar rangka yang tersedia dalam bahan ajar sebagai alat bantu agar materi tersampaikan dengan baik dan jelas. Setelah itu siswa kemudian dibagi menjadi lima kelompok sesuai dengan jumlah jenis teka-teki dalam bahan ajar, kelompok dibentuk secara acak. Kemudian guru menjelaskan cara memecahkan teka-teki dengan memecahkan satu teka-teki sebagai contoh. Setelah mengerti, siswa pun memecahkan teka-teki secara berkelompok sesuai dengan jenis teka-teki yang diberikan.

Setelah kegiatan belajar mengajar selesai, peneliti kemudian mengumpulkan lembar observasi dari semua observer. Hasil observasi dapat dilihat pada bagian lampiran C. dari hasil observasi tersebut, dapat diketahui bahwa selama proses pembelajaran berlangsung, siswa selalu semangat dan tidak nampak bosan. Mereka bekerja sama untuk memecahkan teka-teki yang telah tersedia, bila ditanya, mereka dengan semangat berebutan untuk menjawab. Setelah itu peneliti mengumpulkan kembali bahan ajar yang dibagikan untuk melihat ada tidaknya kritik dan saran yang diberikan, dan melihat jawaban dari setiap kelompok.

Setelah dilakukan uji coba, peneliti meminta para siswa untuk memberikan kritik dan saran untuk bahan ajar yang telah dikembangkan, namun peneliti tidak mendapatkan kritik dan saran apapun dari siswa sehingga peneliti tidak melakukan revisi apapun. Sehingga peneliti menganggap bahan ajar ini siap untuk dikemas.

dari kegiatan diatas, peneliti memperoleh beberapa gambaran mengenai kebutuhan siswa dan pengembangan bahan ajar riddle story book yaitu; 1) Bahan ajar yang dikembangkan dalam penelitian dan pengembangan ini adalah bahan ajar riddle story book. Riddle story book berarti sebuah buku yang di dalamnya berisikan cerita teka-teki. Riddle story tersebut merupakan ciri khas dari bahan ajar yang dikembangkan peneliti. Peneliti memilih teka-teki jenis riddle story dengan beberapa alasan, di antaranya karena masih sangat jarang buku paket maupun bahan ajar biologi yang menggunakan riddle story selain itu penggunaan teka-teki juga dapat memberikan kesan yang baru dalam menyajikan dan menjawab soal, selain untuk pembelajaran juga sangat baik digunakan sebagai hiburan, sehingga siswa dapat belajar namun tidak merasa tegang.

Buku ini ditulis dengan menggunakan bahasa yang semiformal dengan tujuan untuk mengatasi masalah siswa yang kesulitan untuk memahami kalimat dalam beberapa buku paket yang menggunakan bahasa yang cukup sulit untuk dipahami. Buku ini juga didesain dengan bentuk yang kecil sehingga dikatakan mini book untuk membantu mengurangi beban siswa membawa buku paket yang berat sehingga mereka tetap belajar di manapun. Gambar-gambar di dalam buku ini juga ditampilkan dengan kualitas High Defenition (HD) agar nampak jelas dan sesuai dengan realita. Hal ini untuk membantu siswa dalam mengamati gambar agar tidak salah dalam membayangkan bentuk tulang yang sebenarnya walaupun belum melihat torso. 
Tujuan dibuatnya bahan ajar ini adalah sebagai pendamping buku paket khususnya ketika mempelajari materi sistem rangka manusia. Materi yang terdapat di dalamnya dirangkum sedemikian rupa sehingga memberikan informasi yang berisi, padat, dan mudah dipahami. Materi tersebut juga sebagai bahan untuk menyimpulkan jawaban dari teka-teki yang telah disiapkan.

Berdasarkan karakteristik bahan ajar yang telah dikembangkan tersebut yang kemudian dihubungkan hasil analisis daftar cek masalah (DCM) siswa, maka bahan ajar riddle story book adalah bahan ajar yang dibutuhkan siswa untuk membantu dalam kegiatan belajar mengajar. Ketika mereka membutuhkan bahan ajar dengan bahasa yang mudah dipahami, kemudian isinya singkat, padat dan jelas dengan gambar yang menarik serta bentuk soal yang tidak biasa, maka riddle story book ini hadir dan membawa semua yang mereka butuhkan ditambah dengan bentuknya yang mini sehingga tidak membebani mereka ketika hendak membawanya kemana-mana.

2) keefektifan bahan ajar diukur melalui kegiatan uji coba dengan metode field trial. Pada tahap ini bahan ajar akan diberikan pada 32 siswa dalam kelas yang sama yaitu kelas XI Mia 4 SMA Negeri 9 Gowa. Kemudian guru pengampu akan melakukan kegiatan belajar mengajar seperti biasanya sementara peneliti akan melakukan observasi dan dokumentasi aktivitas siswa bersama 4 orang obeserver lainnya. Dalam kegiatan ini, guru juga berperan sebagai observer selama pembelajaran berlangsung.

Berdasarkan hasil observasi kegiatan di atas, dapat diketahui bahwa bahan ajar riddle story book efektif digunakan dalam kegiatan belajar mengajar. Hal ini dapat dilihat dari tabel lembar observasi yang menunjukan bahwa siswa lebih semangat dalam mengikuti pembelajaran dalam hal ini selalu senang selama proses pembelajaran, tidak merasa bosan sampai akhir waktu pembelajaran, dan aktif dalam bertanya ataupun menjawab. Mudah dalam memahami materi yang disajikan, tidak bingung selama proses pembelajaran, mampu mengingat nama-nama tulang dengan mudah, dapat memanfaatkan waktu dengan baik dalam hal ini dapat menyelesaikan pembelajaran sesuai dengan waktu yang telah ditentukan dan dapat belajar di mana saja dengan bahan ajar riddle story book.

Selain dari hasil observasi, kemampuan siswa dalam memecahkan setiap tekateki berdasarkan kelompok juga menunjukan efektifnya bahan ajar riddle story book. Hal ini karena setiap kelompok mampu memecahkan teka-teki dengan benar dan menggunakan analisis yang hampir sempurna sesuai dengan kunci jawaban yang telah dibuat peneliti. Setiap kelompok mampu memecahkan $80 \%$ dari jumlah teka-teki yang disediakan dengan waktu/ yang telah ditentukan.

\section{KESIMPULAN}

Berdasarkan rangkaian penelitian di atas, maka diperoleh hasil penelitian yang dapat disimpulkan bahwa, siswa membutuhkan bahan ajar yang memiliki soal yang menarik, tidak membosankan dan mudah dipahami. Selain itu, siswa juga menginginkan buku atau bahan ajar yang didesain dengan kemasan yang menarik, praktis, mudah dibawa ke 
mana-mana, dan dengan bahasa yang mudah dipahami yang menjadikan bahan ajar riddle story book adalah bahan ajar yang dapat memenuhi kebutuhan siswa. Untuk mengembangkan bahan ajar dengan kriteria tersebut dapat dilakukan dengan memilih model pengembangan 4D yang terdiri dari tahap pendefenisian (define), tahap perancangan (design), tahap pengembangan (develop), dan tahap penyebaran (desseminate) dimana tahap pengembangan dari model 4D digantikan dengan model Borg dan Gall yang terdiri dari validasi ahli, uji pengembangan one to one dan small group investigation, dan uji coba field trial. Dengan begitu dapat diperoleh bahan ajar yang efektif untuk meningkatkan minat belajar siswa.

\section{UCAPAN TERIMAKASIH}

Penyusun menyadari bahwa selama proses penyusunan jurnal ini, penyusun banyak dibantu oleh orang-orang yang sangat luar biasa dimana mereka dengan sabar membimbing, memberi semangat dan mendoakan agar penyusun mendapatkan hasil yang terbaik. Tanpa adanya bantuan mereka, mungkin karya ini tidak akan pernah ada. Oleh karena itu, melalui karya ini pula penyusun ingin menyampaikan beribu ucapan terimakasih yang tulus kepada kedua orang tua tercinta, ayahanda Mustabil dan Ibunda Suriati Mahmud. Terimakasih juga penulis sampaikan kepada; 1) Jamilah, S. Si., M.Si. dan Dr. H. Muh. Rapi, M. Pd. selaku ketua dan sekertaris jurusan Pendidikan Biologi UIN Alauddin Makassar; 2) Dr. M. Yusuf Tahir, M. Ag dan Ainul Uyuni Taufiq, S. Pd., M.Pd. selaku pembimbing I dan II; 3) pihak SMA Negeri 9 Gowa terkhusus kepada ibunda Hilawati, S. Pd. yang telah membantu penulis dalam pelaksanaan penelitian ini; 4) teman-teman khususnya kepada Marwah Ahmad Maulana S. Pd. Resni, S. Pd. Zam Zam Fauziyah, S. Pd. Saifullah, dan muhri yang selalu menemani penyusun selama merantau dan menyusun karya ini; dan yang terakhir kepada seluruh pihak yang penulis tidak dapat sebutkan satu persatu, khususnya pada kalian yang selalu mengucapkan kalimat "kapan selesai".

\section{DAFTAR PUSTAKA}

Alwi, Hasan. (2007). Kamus Besar Bahasa Indonesia. Jakarta: Balai Pustaka.

Asrijal. (2016). Biologi Umum. Makassar: Alauddin University.

Atmazaki. (2003). "Teka-teki dalam Bahasa Minangkabau, suatu Tinjauan Psikolinguistik." Bahtera, Jurnal Penelitian Bahasa, Sastra, dan Pengajarannya, Vol.2 No.3, Januari. Padang: Universitas Negeri Padang.

Brunvand, Jan Harold. (1998). The Study of American Folklore: An Introduction. Norton.

Danandjaja, James. (1984). Folklor Indonesia; Ilmu Gosip, Dongeng, dan Lain-Lain. Jakarta: Grafiti Pers. 
Fitriany, Rizka Ayu Mei dan Herawati Susilo. (2013). "Analisis Hambatan Proses Pembelajaran Biologi dan Cara Pemecahannya dalam Pelaksanaan Kurikulum 2013 Bagi Guru Kelas X SMA Negeri Se-Kota Lamongan.” Skripsi Tidak diterbitkan. Malang: Jurusan Pendidikan Biologi, FMIPA, Universitas Negeri Malang.

Hamidy, U. U. (1995). Kamus Antropologi Dialek Melayu Rantau Kuantan, Riau. Riau: Unri Press.

Jordan-Smith, Paul. (2004). "Riddles: Perspectives on the Use, Function, and Change in a Folklore Genre.” Journal of American Folklore; 117, 464. Amerika: Arts \& Humanities Database.

Mustafa, Fahim. Agar Anak Anda Gemar Membaca. Jakarta: Hikmah Kelompok Mizan Ningsih, Ayu Gustia, Atmazaki dan R., Syahrul. (2013). "Peningkatan Keterampilan Berbicara Melalui Metode Bermain Teka-Teki Siswa Kelas X MAS-TI Tabek Gadang Kabupaten Lima Puluh Kota.” Jurnal Bahasa, Sastra dan Pembelajaran. Volume 1 Nomor 3, Oktober. Padang: Universitas Negeri Padang.

Noss, Philip A. (2006). "Gabaya Riddles in Changing Times." Research in African Literatures; 37. 2. Amerika: Arts \& Humanities Database.

Schiller, Pam. (2005). 20 Tips Start Smart Memompa Kecerdasan Sejak Dini. Terj. Damaring Tiyas W. Jakarta: Erlangga.

Suartika, K., I. B. Arnyana, dan G A. Setiawan. (2013). "Pengaruh Model Pembelajaran Kooperatif Tipe Group Investigation (GI) Terhadap Pemahaman Konsep Biologi dan Keterampilan Berpikir Kreatif Siswa SMA.” E-Journal Program

Sutopo, Ariesto Hadi dan Adrianus Arief. (2010). Terampil Mengolah Data Kualitatif dengan NVIVO. Jakarta: Kencana Prenada Media Group.

Tarigan, Henry Guntur. (2007). Berbicara sebagai Suatu Keterampilan Berbahasa. Bandung: Angkasa.

Thompson, George. (1999). "Riddles and Enigmas." Journal of the American Oriental Society; 199, 2. Amerika: Arts \& Humanities Database.

Wahyudi, Benny Satria, Hariyadi, Slamet dan Hariani, Sulifah Aprilya. (2014). "Pengembangan Bahan Ajar Berbasis Model Problem Based Learning pada Pokok Bahasan Pencemaran Lingkungan untuk Meningkatkan Hasil Belajar Siswa Kelas X SMA Negeri Grujugan Bondowoso.” Pancaran, Vol. 3, No. 3, Agustus. Jember: Universitas Jember

Yusuf T,, M., Muhammad Rusydi Rasyid, M. Rapi. "Efisiensi Pembelajaran PAI melalui Kegiatan Perbaikan Kinerja Berkelanjutan pada Kelompok Kegiatan Guru PAI Kecamatan Rappocini Kota Makassar” Al-Qalam, Vol. 23 No. 2 (2016), h. 248 - 254, Kementerian Agama, Balai Penelitian dan Pengembangan Keagamaan Makassar.

Yusuf T., M. Teori Belajar dalam Praktek (Makassar, Alauddin Press, 2013). 